\title{
COMPARE SILICA NANOPARTICLES WITH TWO INSECT PATHOGENS IN CONTROLLING COTTON LEAFWORM, Spodoptera littoralis BOISD. IN EARLY SUGAR BEET PLANTATION AND THEIR EFFECTS ON SOME ASSOCIATED NATURAL ENEMIES Fathia A. Salem
}

Plant Protection Research Institute, Agricultural Research Center, Egypt

\begin{abstract}
The application of nanomaterials in agriculture aims in particular to reduce insecticides in plant protection, minimize nutrient losses in fertilization, and increase yields through optimized nutrient management. So, it could be look for alternative method to control Spodoptera littoralis Boisd. This experiment was conducted out at El-Riad region, Kafr El-Sheikh Governorate, during two successive seasons 2014 and 2015 to compare the efficacy of silica nanoparticles (SiNPs) at three rates (20, 40 and $60 \mathrm{~g} / \mathrm{fed}$ ) with two pathogens dipel DF at $200 \mathrm{~g} / \mathrm{fed}$ and biofly $300 \mathrm{ml} / \mathrm{fed}$ in controlling S. littoralis in early sugar beet plantation. Also, this study aimed to show the negative side effects on some associated natural enemies; true spider, Chrysoperla carnea (Stephens) and Coccinella spp. Results showed the highest rate of SiNPs (60 g/fed) was the highest effectiveness in reducing the numbers of S. littoralis; 59.75 and $61.77 \%$ reduction in larvae during two season, respectively. While the two tested insect pathogens came in the second category in controlling the insect. On the other hand biofly showed the highest side negative effect on associated predators followed the dipel DF, while the lowest effect recorded from SiNPs at low rate $(20 \mathrm{~g} / \mathrm{fed})$.
\end{abstract}

Keywords: silica nanoparticles, cotton leafworm, sugar beet, natural enemies

\section{INTRODUCTION}

Sugar beet, Beta vulgaris L. is one of two principal sugar crops and provides about $40 \%$ of the world sugar production and represents the second source, after sugar-cane. This crop is annually planted in Egypt and 55\% of the cultivated area is concentrated in Kafr El-Sheikh Governorate (Abou El-Kassem, 2010).

Sugar beet plants attract numerous insect species during growing season. These insects varied in their feeding processes, needs of living and some of them can cause economic damage when they feed on the plants during their early growth stages (Shalaby, 2001).

However, in some cases, some common insect pests like the cotton leafworm, Spodoptera littoralis Biosd. could be more dangerous than specific ones. Because the climate change that keeps the temperature relatively high throughout September, S. littoralis can severely attack the seedlings of sugar beet causing large bare batches in the field and results in high economic losses (Abou El-Kassem, 2010 and El-Mahalawy, 2011).

A knowledge of the sugar beet ecosystem is essential to develop an insect control strategies which from a backbone of integrated pest management (IPM) program. control of sugar beet insects can be achieved through optimizing the cultural practices such as planting dates, susceptibility of sugar beet varieties, fertilization and addition to insect pathogens and the beneficial insect inhabiting sugar beet crop (Amin et al., 2008 and Tohamy et al., 2008).

Nanotechnology draws its name from the prefix "nano". A nanometer is one-billionth of a meter-a distance equal to two to twenty atoms (depending on what type of atom) laid down next to each other. Nanotechnology refers to manipulating the structure of matter on a length scale of some small number of nanometers, interpreted by different people at different times as meaning anything from $0.1 \mathrm{~nm}$ (controlling the arrangement of individual atoms) to $100 \mathrm{~nm}$ or more (anything smaller than microtechnology). Richard Feynman was the first scientist to suggest that devices and materials could someday be fabricated to atomic specifications. "The principles of physics, as far as I can see, do not speak against the possibility of maneuvering things atom by atom." This concept was expanded and popularized in a 1986 book Engines of Creation by K Eric Drexler, who applied the term nanotechnology to Feynman's vision (Drexler et al., 1992).

In research experiments nano silica has been reported to provide insecticide activity on its own, through desiccation of insects' cuticles. It has also been successfully applied as a thin film to boost cereal germination and decrease fungal growth (Qhobosheane et al., 2001). However, nano silica is not a preferred auxiliary in crop protection products due to the adverse effect upon inhalation.

The efficiency of the fungus Beauveria bassiana Vuill. As biological control agent against sugar beet insect pests were tested in the laboratory and in the field on Scrobipalpa ocellatella (Boyd) (El-Sufty, 1987 and Mansour, 1999) or mixing the fungus, B. bassiana with the conventional insecticides (El-Sufty and Abbasy 1987)

The efficacy of $B$. bassiana were recorded using the fungus (Biofly) at a rate of $3 \times 10^{7}$ conidia/ml which gave 43.63 and $47.91 \%$ for $S$. ocellatella twenty days after treatment (Metwally et al., 2004). Also, the insect population of $S$. ocellatella reduced by 36.32 and $42.13 \%$ in the two seasons of study in using Bacillus thuringiensis.

Therefore the aim of this study to evaluate the efficiency of silica nanoparticles compared with two insect pathogens in controlling the cotton leafworm, $S$. littoralis in early plantation of sugar beet and the side effect on some associated predators. 


\section{MATERIALS AND METHODS}

This experiment was carried out at El-Riad region, Kafr El-Sheikh Governorate, during two successive seasons 2014 and 2015. The experimental area was prepared, and sown with Pleno sugar beet cultivar on mid of August every season. This date of sowing was selected to mimic the infestation of cotton leafworm, S. littoralis occurs in sugar beet fields, while the temperature is high. All recommended cultural practices were applied along the growing seasons without insecticide applications. Efficacy of the examined materials against target insect started when the egg masses reach to 10 per 100 plant, coincide almost one month after sowing.

To evaluate the reduction of $S$. littoralis larvae dipel DF at $200 \mathrm{~g} / \mathrm{fed}(6.4 \% \mathrm{WP})$ a bio preparation of
Bacillus thuringiensis var. kurstaki and Biofly at 300 $\mathrm{ml} / \mathrm{fed}\left(3 \times 10^{7}\right.$ conidia/ml) having Beauveria bassiana. The silica nanoparticles (SiNPs) was obtained from Nanotech Egypt Company Limited, Cairo, Egypt. It's size was approximately $18 \mathrm{~nm}$ with a purity of $95 \%$. The Transmission Electronic Microscope (TEM) image of the silica nanoparticles is shown in Fig. 1. (rates of SiNPs 20, 40 and $60 \mathrm{~g} / \mathrm{fed}$.). The experimental area was divided into 24 plots [(5 treatments + control $) \times 4$ replications] in Randomized Complete Block Design (RCBD). The first treatment was the control which sprayed with water. The others were treated with the different concentrations of SiNPs and two pathogens (Dipel DF and Biofly) using CP3 sprayer at 200 liter water per feddan. The normal cultural practices of growing were applied as usual without using any insecticides.

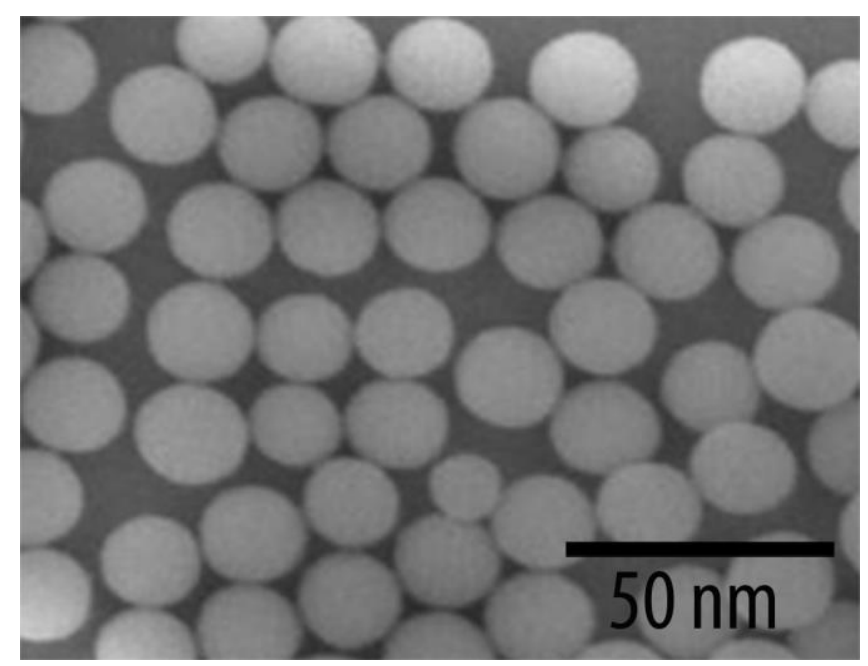

Fig. (1): Transmission electron micrograph (TEM) of silica nanoparticle

The sugar beet plants were examined before and after 1, 3, 7 and 10 days after treatments for each examination, 10 plants/plot were inspected to count the life larvae. Population reductions due to treatments were calculated and compared with the insect numbers in untreated plots (control).

Percentage of infestation reduction was estimated according to the formula of Henderson and Tilton (1955) as follows:

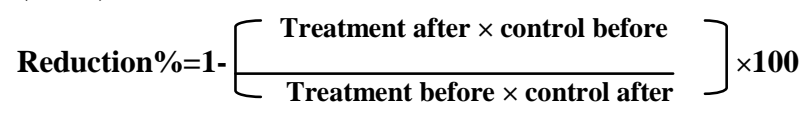

To study the effect of these treatments on the associated predators, numbers of true spiders, Coccinella sp. (adults and larvae) and C. carnea (larvae) were counted per 10 sugar beet plants just before treatments, and then 1, 3, 7 and 10 days after treatments. Also, the reductions in natural enemies were calculated with the same equation.

The obtained data were treated statistically according to the method of Duncan Multiple Range Test (Duncan, 1955).

\section{RESULTS AND DISCUSSION}

Application of two pathogens, Bacillus thuringiensis (Dipel DF) and Beauveria bassiana (Biofly) compared with silica nanoparticles (SiNPs) in controlling $S$. littoralis larvae in early sugar beet plantation during the two successive seasons, 2014 and 2015.

a. Reduction in Spodoptera littoralis Boisd. larvae:

Data illustrated in Table (1) showed the reduction percentage of $S$. littoralis resulted from using SiNPs (three concentrations), dipel DF and biofly during the first season 2014.

After one day of treatments the high concentration of SiNPs was highly effective which recorded $35.54 \%$ reduction of larvae numbers followed by medium rate of SiNPs (40 g/fed) reduced $22.35 \%$. After three, seven and ten days SiNPs (60 g/fed) were recorded $68.44,65.72$ and $69.31 \%$ reduction in larvae numbers, respectively. While the lowest reductions were recorded by using SiNPs with low concentrations 20 and $40 \mathrm{~g} / \mathrm{fed}$. The two insect pathogen showed moderately reduction in $S$. littoralis larvae followed by the high rate of SiNPs. 
The population reduction as overall average of $S$. littoralis larvae in early sugar beet plantation was shown in Fig. 2. The statistical analysis showed significant differences between all treatments. The highest reduction was obtained in using the high concentration of SiNPs $(59.75 \%)$ followed by dipel DF and biofly with 34.30 and $30.11 \%$, respectively. There are not significant differences among SiNPs 20 and $40 \mathrm{~g} / \mathrm{fed}$ which recorded 24.43 and $27.41 \%$, respectively.

Table (1): Reduction percentage of $S$. littoralis in early sugar beet plantation at El-Riad region, Kafr ElSheikh Governorate during the first season 2014.

\begin{tabular}{|l|c|c|c|c|c|}
\hline \multirow{2}{*}{ Treatment } & \multirow{2}{*}{ Rate/fed. } & \multicolumn{4}{|c|}{ Days after treatment } \\
\cline { 3 - 6 } & & $\mathbf{1}$ & $\mathbf{3}$ & $\mathbf{7}$ & $\mathbf{1 0}$ \\
\hline \multirow{3}{*}{ Silica nanoparticles } & $20 \mathrm{~g}$ & 18.13 & 20.62 & 25.32 & 33.63 \\
\cline { 2 - 6 } & $40 \mathrm{~g}$ & 22.35 & 24.65 & 37.44 & 25.21 \\
\cline { 2 - 6 } & $60 \mathrm{~g}$ & 35.54 & 68.44 & 65.72 & 69.31 \\
\hline Dipel DF & $300 \mathrm{~g}$ & 12.16 & 15.56 & 54.35 & 55.12 \\
\hline Biofly & $300 \mathrm{ml}$ & 15.23 & 17.12 & 39.43 & 48.65 \\
\hline
\end{tabular}

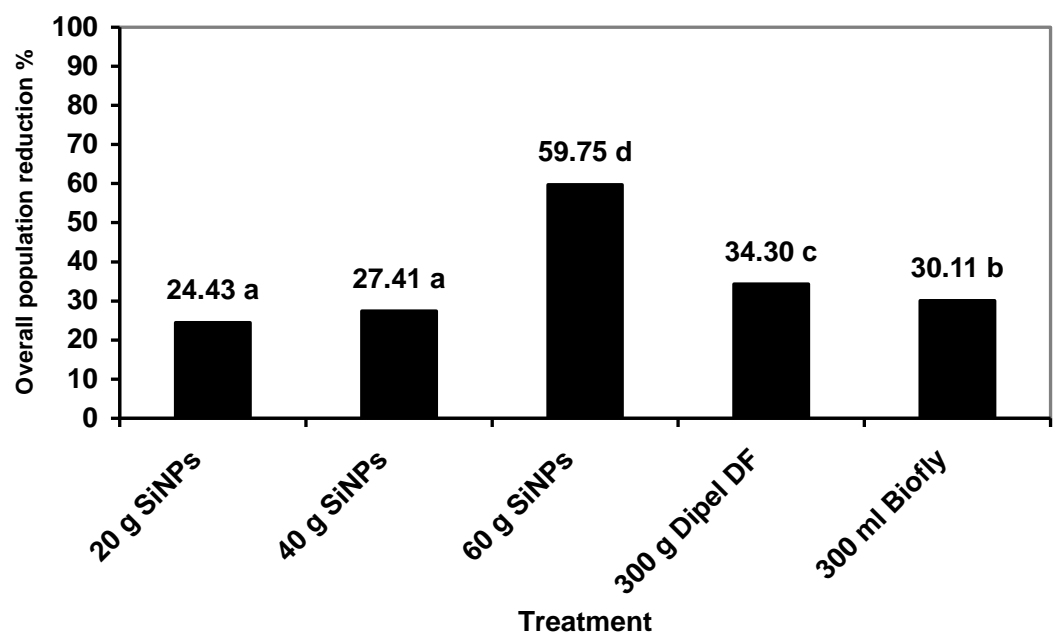

Fig. (2): Overall population reduction percentage of the cotton leafworm, $S$. littoralis in early sugar beet plantation during the first season 2014.

Means followed by a common letter are not significantly different at the $5 \%$ level by DMRT

In the second season 2015, data in Table (2) showed after one day of treatments the SiNPs; 60,40 and $20 \mathrm{~g} / \mathrm{fed}$. were recorded 40.14, 20.15 and $16.21 \%$ reduction in $S$. littoralis larvae, respectively followed by dipel and biofly at 13.44 and $10.26 \%$, respectively. After one week the high concentration of SiNPs $(60$ $\mathrm{g} / \mathrm{fed}$ ) was recorded $66.57 \%$ followed by dipel DF which recorded $55.23 \%$, while biofly recorded $33.56 \%$.

The overall averages of population reduction percentage of the cotton bollworm, S. littoralis numbers after treatments were shown in Fig. 3. The statistical analysis showed significant differences between treatments. The highest effectiveness was recoded by high rate of SiNPs (60 g/fed.) $61.77 \%$ reduction followed by dipel DF and SiNPs (40 g/fed.) with 35.48 and $29.74 \%$ reduction, respectively. The biofly and lowest SiNPs (20 g/fed.) were recorded 24.09 and $23.94 \%$ reduction, respectively without significantly.

The silica nanoparticles enhanced the plant tolerance against cotton leafworm, S. littoralis which increase the hardness plants (Borei et al., 2014 and ElSamahy, 2015). So, the hardness on sugar beet leaves reduce the ability of larvae eat.

Table (2): Reduction percentage of $S$. littoralis in early sugar beet plantation at El-Riad region, Kafr ElSheikh Governorate during the second season 2015.

\begin{tabular}{|l|c|c|c|c|c|}
\hline \multirow{2}{*}{ Treatment } & \multirow{2}{*}{ Rate/fed. } & \multicolumn{4}{|c|}{ Days after treatment } \\
\cline { 3 - 6 } & & $\mathbf{1}$ & $\mathbf{3}$ & $\mathbf{7}$ & $\mathbf{1 0}$ \\
\hline \multirow{3}{*}{ Silica nanoparticles } & $20 \mathrm{~g}$ & 16.21 & 19.88 & 23.95 & 35.71 \\
\cline { 2 - 6 } & $40 \mathrm{~g}$ & 20.15 & 25.37 & 35.81 & 37.63 \\
\cline { 2 - 6 } & $60 \mathrm{~g}$ & 40.14 & 69.52 & 66.57 & 70.84 \\
\hline Dipel DF & $300 \mathrm{~g}$ & 13.44 & 16.15 & 55.23 & 57.11 \\
\hline Biofly & $300 \mathrm{ml}$ & 10.26 & 13.31 & 33.56 & 39.23 \\
\hline
\end{tabular}




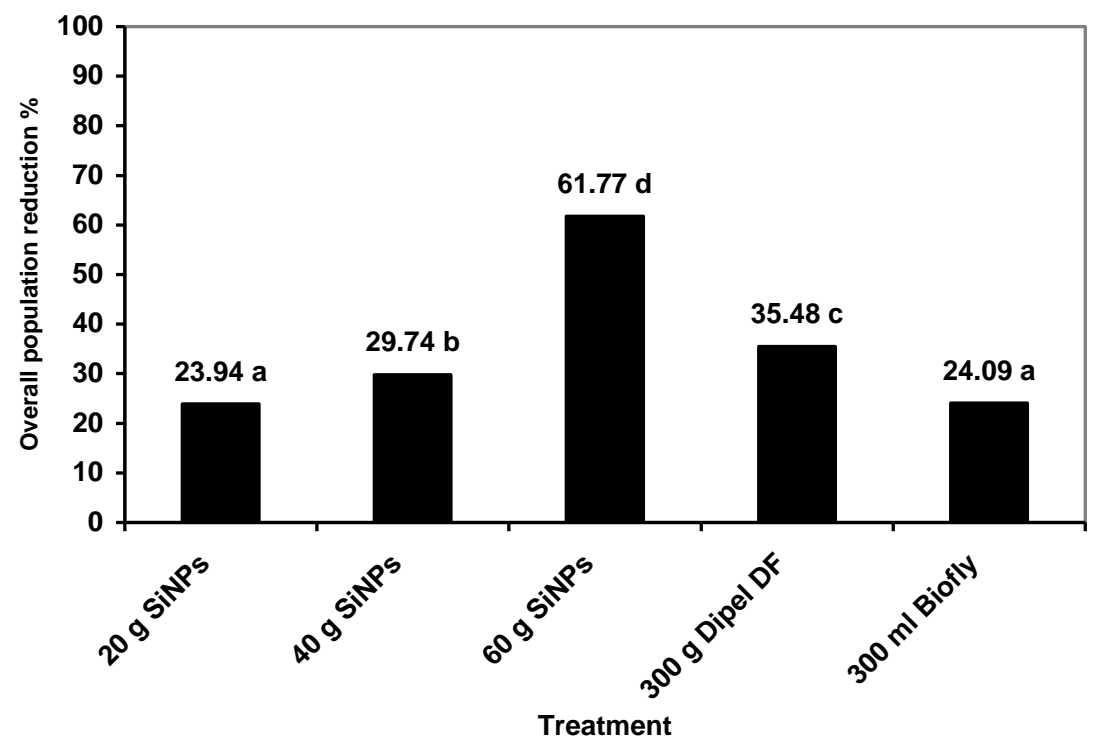

Fig. (3): Overall population reduction percentage of the cotton leafworm, Spodoptera littoralis in early sugar beet plantation during the second season 2015 .

Means followed by a common letter are not significantly different at the $5 \%$ level by DMRT

b. Reduction in true spiders, Chrysoperla carnea (Stephens) and Coccinella spp.

The reduction percentage in some natural enemies associated with cotton leafworm, S. littoralis in early sugar beet plantation during two seasons; 2014 and 2015 were shown in Table (3).

The highest negative side effect of tested materials on true spiders, C. carnea and Coccinella spp. at mean 37.06, 51.65 and $40.00 \%$ reduction, respectively were obtained in using biofly during two seasons. The dipel DF come in the second order in negative side effect. The lowest rate of SiNPs (20 g/fed.) showed the lowest negative effect on three associated natural enemies.

Table (3): Reduction in some natural enemies associated with cotton leafworm, $S$. littoralis in early sugar beet plantation at El-Riad region, Kafr El-Sheikh Governorate during two seasons 2014 and 2015.

\begin{tabular}{|c|c|c|c|c|c|c|c|c|c|c|}
\hline \multirow{2}{*}{ Treatment } & \multirow{2}{*}{ Rate/fed } & \multicolumn{2}{|c|}{ True spiders } & \multirow{2}{*}{ Mean } & \multicolumn{2}{|c|}{ Chrysoperla carnea } & \multirow{2}{*}{ Mean } & \multicolumn{2}{|c|}{ Coccinella spp. } & \multirow{2}{*}{ Mean } \\
\hline & & 2014 & 2015 & & 2014 & 2015 & & 2014 & 2015 & \\
\hline \multirow{3}{*}{$\begin{array}{l}\text { Silica } \\
\text { nanoparticles }\end{array}$} & $20 \mathrm{~g}$ & 18.02 & 17.31 & $17.67 \mathrm{a}$ & 24.15 & 23.22 & 23.69 & 18.44 & 15.67 & $17.06 \mathrm{a}$ \\
\hline & $40 \mathrm{~g}$ & 22.36 & 20.58 & $21.47 b$ & 29.34 & 35.11 & 32.23 & 25.27 & 23.58 & $24.43 b$ \\
\hline & $60 \mathrm{~g}$ & 20.07 & 29.52 & $24.80 \mathrm{c}$ & 35.44 & 36.54 & 35.99 & 26.48 & 25.17 & $25.83 b$ \\
\hline Dipel DF & $200 \mathrm{~g}$ & 25.63 & 22.66 & $24.15 \mathrm{c}$ & 37.23 & 35.17 & 36.20 & 40.22 & 39.74 & $39.98 \mathrm{c}$ \\
\hline Biofly & $300 \mathrm{ml}$ & 38.22 & 35.89 & $37.06 \mathrm{~d}$ & 50.67 & 52.63 & 51.65 & 41.45 & 38.54 & $40.00 \mathrm{c}$ \\
\hline
\end{tabular}

Means followed by a common letter are not significantly different at the $5 \%$ level by DMRT

Data showed SiNPs have moderately negative effects on associated natural enemies; true spiders, $C$. carnea and Coccinella spp. and can be control the cotton leafworm, $S$. littoralis in early sugar beet plantation. The obtained results agreement with the results obtained from El-Samahy et al., 2015 who found that SiNPs in $20 \mathrm{~nm}$ with purity $99.99 \%$ in high concentration reduced the number of $S$. littoralis and associated predators, while the low concentration give satisfied control and low-risk in associated predators.

\section{REFERENCES}

Abou-El-Kassem, A. B. (2010). Ecological and biological studies on some insects of sugar beet plants at Kafr El-Sheikh governorate. Ph.D. Thesis, Fac. Agric., Kafr El-Sheikh Univ., pp. 221.
Amin, A. H.; A. Helmi and S. A. El-Serwy (2008). Ecological studies on sugar beet insects at Kafr El-Sheikh Governorate, Egypt. Egypt J. Agric. Res., 86 (6): 2129 - 2139.

Borei, H. A.; M. F. M. El-Samahy; Ola A. Galal, and A. F. Thabet, (2014). The efficiency of silica nanoparticles in control cotton leafworm, Spodoptera littoralis Boisd. (Lepidoptera: Noctuidae) in soybean under laboratory conditions. Glob. J. Agric. Food Safety Sci., 1 (2): 161-168.

Drexler, K. E.; C. Peterson and G. Pergamit. (1992). Unbounding the Future: The Nanotechnology Revolution New York: William Morrow.

Duncan, D. B. (1955). Multiple Range and Multiple F. test. Biometrics, 11: 1-24. 
El-Mahalawy, N. A. (2011). Ecological and biological studies on some sugar beet insects. M. Sc. Thesis, Fac. Agric., Tanta Univ.

El-Samahy, M. F. M. (2015). Compare the efficacy of sodium metasilicate with silica nanoparticles against Spodoptera littoralis (Boisd.) in the laboratory. Egypt. J. Agric. Res., 93 (1) (B): 553 560.

El-Samahy, M. F. M.; I. F. Khafagy and Asma M. A. El- Ghobary (2015). Efficiency of silica nanoparticles, two bioinsecticides, peppermint extract and insecticide in controlling cotton leafworm, Spodoptera littoralis Boisd and their effects on some associated natural enemies in sugar beet field. J. Plant Prot. and Path., Mansoura Univ., Vol. 6 (9): 1221 - 1230,

El-Sufty, R. (1987). Insecticidal activity of a biopreparation of the fungus, Beuveria bassiana (Balsamo) Vuillemin, "Boverol" against the sugar-beet mining moth. J. Agric. Res., Tanta Univ., 13 (4): 1165 - 1176.

El-Sufty, R. and M. Abbassy (1987). Effect of certain compounds on growth and efficacy of the entomopathogenic fungus Beuveria bassiana Balsamo. Vuillemin. J. Agric. Res., Tanta Univ., 13 (4): $1154-1164$.
Henderson, C. F. and E. W. Tilton (1955). Tests with acaricides against the brown wheat mite. J. Econ. Entomol., 48: 157-161.

Mansour, H. A. M. (1999). Studies on the entomopathogenic fungus Beauveria bassiana as a biological control agent for some economically important insects. Ph. D. Thesis, Fac. Agric., Tanta Univ.

Metwally, M. M.; H. M. Mansour and G. A. Shalaby (2004). Efficacy of the bacterium Bacillus thuringiensis (Berl.) and the fungus, Beauveria bassiana (Bals.) as biological control agents against some sugare beet insects in the field. $J$. Agric. Sci. Maonsoura Univ., 29 (1): 443 - 449.

Qhobosheane, M.; S. Santra; P. Zhang and W. Tan (2001). Biochemically functionalized silica nanoparticles. Analyst;126: $1274-1278$.

Shalaby, G. A. M. (2001). Ecological studies on some important sugar beet pests and natural enemies and their control. Ph.D. Thesis, Fac. Agric., Kafr El-Sheikh, Tanta Univ., pp. 141.

Tohamy, H. T.; M. I. El-Khouly and A. M. El-Rawy (2008). Effect of nitrogen fertilization on the infestation by beet fly and sucking insects on productivity of sugar beet in El-Minia Governorate. J. Agric. Sci., Mansoura Univ., 33 (1): $495-499$.

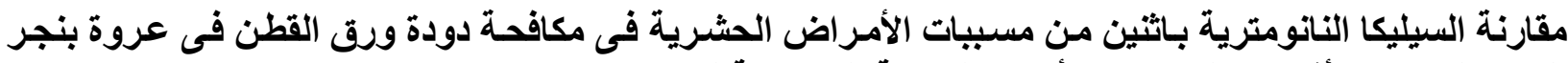

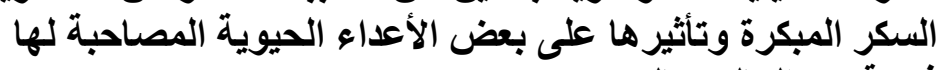
فتحية عبد الخالق سالم وتأير معهد بحوث وقايةً النباتات، مركز البحوث الزراعية، مصر

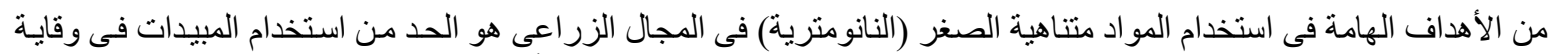

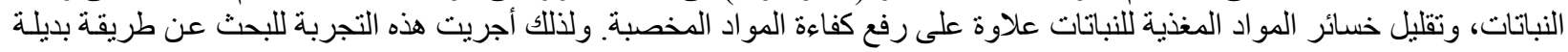

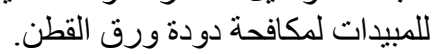

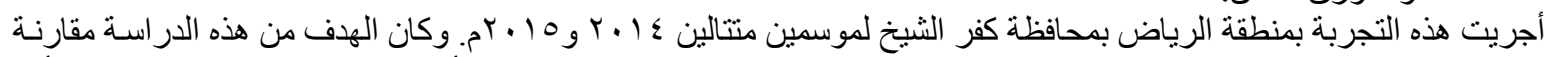

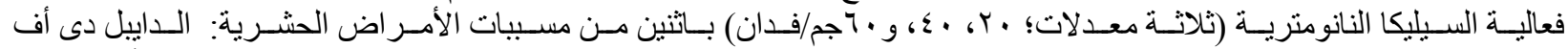

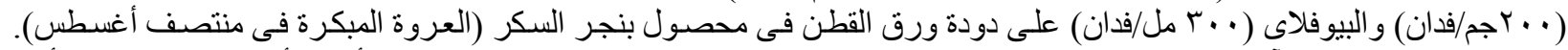

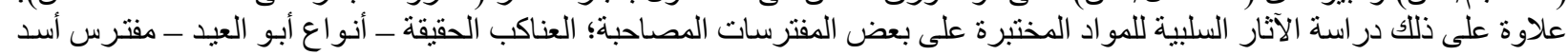

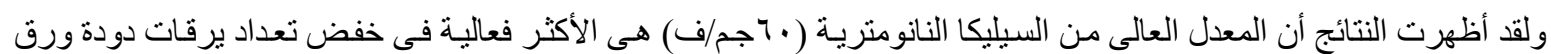

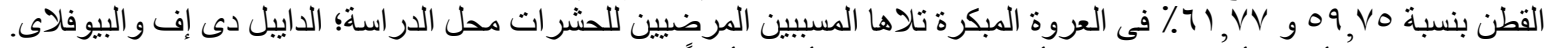

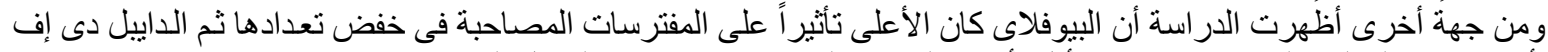

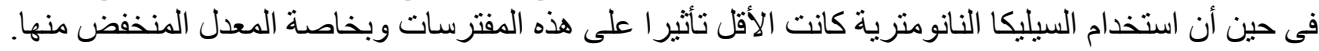

